\title{
Recommended lines of Kashubian Lakeland landscape management in the light of their quarter-century transformation in the vicinity of Gdańsk agglomeration
}

\author{
Mariusz Kistowski \\ University of Gdańsk, Faculty of Oceanography and Geography, Institute of Geography, \\ Department of Physical Geography and Environmental Management, \\ J. Bażyńskiego 4 St, 80-309 Gdańsk, Poland, \\ e-mail: geomk@univ.gda.pl
}

Received: 11 October 2017 / Accepted: 26 January 2018

\begin{abstract}
Planning of spatial development in suburban areas requires considering natural and landscape criteria. In the studied transect Gdańsk - Kartuzy $\left(189 \mathrm{~km}^{2}\right)$, which has undergone a dynamic development of build-up area, in the last quarter of a century, we carried out analysis and assessment of urban sprawl in the years 1987-2012 and its relationship with the features of the terrain as well as the degradation of visual landscape values - based on a broad set of numerical spatial data. There is a little negative correlation of the frequency of the built environment with relative heights and a positive with intensity degradation of visual landscape values. Within the given period, the increase in built-up area amounted to $137 \%$ and this trend may continue, in the light of the findings of the studies on conditions and directions of spatial development of municipalities. The latest development, to a small extent, interferes with elements of ecological networks: patches and corridors, however, the planned investments, especially metropolitan bypass road, can reduce the efficiency of the functioning of the ecological corridor of the Radunia valley. In order to present recommendations in the scope of the landscape management and protection, the area was divided into 12 zone types, which were assigned with different spatial policies. The largest of them include large forest complexes (A), farmland dominated by fields (D), multi-functional rural settlements $(F)$ and suburban areas $(\mathrm{G})$.
\end{abstract}

Key words: landscape management, urban-sprawl, spatial development, ecological patches and corridors, Gdańsk agglomeration.

\section{Introduction}

The development of urban sprawl in the area surrounding cities, especially large ones, defined as suburbanization, is one of the greatest contemporary civilization problems. Its effects have varying vector and intensity, however, according to many researchers, the negative effects outweigh the positive (Kamieniecki, 2002; Antrop, 2004; Urban sprawl in Europe, 2006). These processes occur also around the Tri-City and, for more than a quarter of a century, their intensity have increased. It manifests particularly through the change in the structural cover and land use, consisting mainly in a decrease in agricultural area, including natural grasslands and peatlands as well as an increase in wastelands and built-up areas, and an increase in the number of inhabitants of the towns surrounding the main cities of the metropolitan area (Gdańsk - Sopot - Gdynia), with a corresponding decline within the cities themselves (Sołtys, 2006; Kistowski \& Korwel-Lejkowska, 2009).

The aim of the study is to identify the spatial aspects of the suburbanization processes in the context of natural conditions and the outlook for environment protection 
and development of the selected section of environment of the Tri-City Metropolitan Area. The broader study on the verification of the forms of nature protection around the Tri-City (Kistowski, 2015) became the pretext for the implementation of the presented analysis and assessment. The characteristics of the structure of the natural environment as of 2012 serves as their background. Archival cartographic materials, used in the analysis of changes in the developed areas, refer to the second half of the 80 s of the 20th century (around year 1987).

\section{The study area}

The study area includes the transect located between Gdańsk and Kartuzy, which covers an area of $189 \mathrm{~km}^{2}$ $\left(27 \times 7 \mathrm{~km}^{2}\right)$. It is situated in the central part of the Pomeranian Province, in the Kartuzy and Gdańsk districts. In terms of area, mixed urban-rural municipalities dominate: Żukowo (39.2\% of the area) and Kartuzy (26.4\%), rural municipality Kolbudy (17.1\%) and the City of Gdańsk (10.5\%) (Fig. 1). A small part of the area is covered by rural municipality of Somonino, Pruszcz Gdański and Przodkowo. In physical and geographical terms, the whole area is located in the Kashubian Lake District mesoregion. The area is dominated by micro-regions of moraine elevations (Fig. 3) in the eastern part of Gdańsk Upland (38\% of the area), in the central - Skrzeszewo-Grabowo Upland $(26.6 \%)$, and the western - Kartuzy-Kiełpino Upland $(31.3 \%)$ and Kosy Upland (2.2\%). The Radunia Valley $(5.5 \%)$ is the axis of the area. Also Kartuzy Channel and valleys of Strzelniczka and Klasztorna Struga cover small parts of the area (Kistowski \& Szydłowski 2015). The geological surface is dominated by sandy and clay soils, while at the bottom of valleys peat dominates. There are several medium-sized lakes and hundreds of small reservoirs in the area. Their number and size increases in a westerly direction.

The largest lakes are: Sitno (62.4 hectares), Klasztorne Duże (57.3 ha), Głębokie (50.7 ha), Mezowskie (39.3 ha), Karczemne (39.1 ha), Otomińskie (38.7 ha). Nearly half of the study area is covered by the forms of nature protection (Fig. 1): 4 nature reserves (including the largest "Radunia River Gil"), a fragment of the Kashubian Landscape Park (1.8\% of the area) and 4 areas of protected landscape (Kartuski, the Valley of Radunia, Otomiński and Przywidzki) (total 45.5\%). In the eastern part of the area, there is a Tri-City bypass road, while the line of Pomeranian Metropolitan Railway from Gdańsk-Wrzeszcz to Kartuzy has its course similar to the latitudinal.

\section{Data sources and study methods}

The geospatial analysis is crucial for methodology of presented studies. In the light of previous experiences, Geospatial technology is very useful tool in analysis of urbansprawl processes in various regions of the world (i.e. Ahmad \& Goparaju, 2016).

A wide range of information and software for data analysis was used in the study. The main materials which were used are listed in Table 1 for the main stages of the analysis and evaluation carried out during the research.

Types of land cover and use have been identified on the bases of experience, among others, in creating data base Corine Land Cover (Manakos \& Braun, 2014). 18 types of land cover were identified within the study area. The analysis uses digital elevation model with a resolution of $1 \mathrm{~m}$ generalized - in order to speed up calculations - up to a resolution of $5 \mathrm{~m}$. ArcGIS, MapInfo and Saga GIS software were used in the analysis and visualization. Drafts prepared by Pomeranian Office of Regional Planning was the starting point for the determination of ecological patches and corridors (Studium korytarzy..., 2014). Their range has been clarified and supplemented. During the delimitation of those elements of the ecological structure, mainly landscape approach was applied. It was based on the study of the structural features of the landscape and used in geoecology, where corridors are defined as "a relatively narrow strip of land that differs from the surrounding matrix" (Forman, 1995). To a small extent, meta-population approach was also included, in which corridor is defined as "an area that allows migration of plants, animals and fungi" (Ustawa [Nature Conservation Act]..., 2018; Richling \& Solon, 2011). Among the most important elements of the landscape covered by the patches as well as ecological corridors, we can find:

- flowing and standing waters, marshes and other components of a wetland;

- concave (valley, canyon) forms of relief, guiding the migration of species and favoring the shallow ground water and surface waters stagnation;

- well-preserved non-forest communities and valuable natural areas;

- selected localities of protected plants and animals;

- forest ecosystems, with particular emphasis on boggy, riparian and alder woodlands and older than 140 years;

- well preserved and moderately deformed forest communities;

- lines and strands trees with length over $500 \mathrm{~m}$, performing the functions of local ecological corridors, together with other elements landscape.

Analysis and evaluation of the degradation of visual landscape values was carried out in several stages, using, 

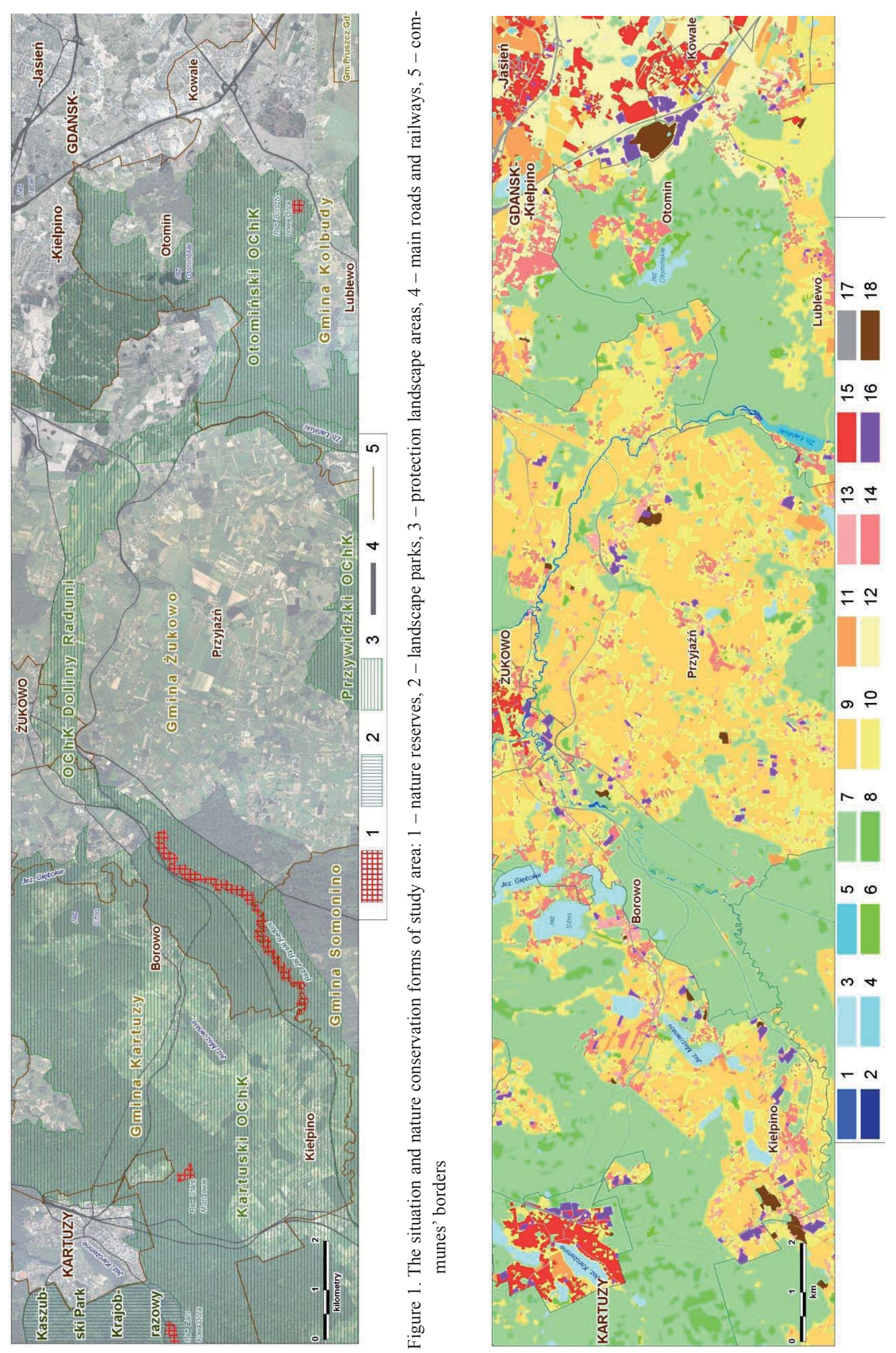

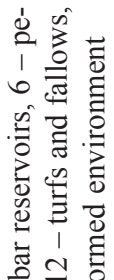

n)

की

苛

के สี

릴

ㄱ

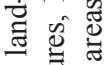

敢

坖

$\checkmark$ 元

:

।

은 1

즙

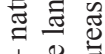

क तै

के

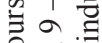

क्ष.

उ范苞

记

ㄴ. 를

के 믈

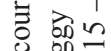

원

$3 \infty$ 징

ज्ञ

学

1

ญ्ष्य

임

踏

पे जै

ठ 尺े

리

告 战

를

i

总 
Table 1. Sources of spatial digital data used in studies

\begin{tabular}{|c|c|c|c|c|c|c|c|c|}
\hline \multirow[b]{2}{*}{ Spatial data type } & \multirow[b]{2}{*}{ Scale } & \multirow[b]{2}{*}{ Form } & \multirow[b]{2}{*}{ Institution } & \multicolumn{5}{|c|}{ Main study stages } \\
\hline & & & & 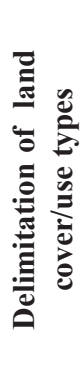 & 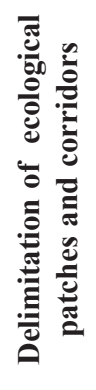 & 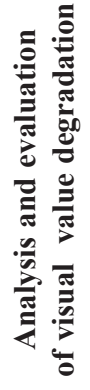 & 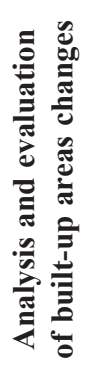 & 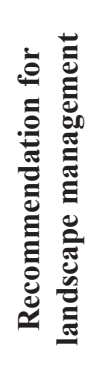 \\
\hline Topographical maps 1965 & $1: 10000$ & raster & WODGiK & $\mathrm{X}$ & $\mathrm{X}$ & $\mathrm{X}$ & $\mathrm{X}$ & $\mathrm{X}$ \\
\hline Topographical maps 1992 & $1: 10000$ & raster & WODGiK & $\mathrm{X}$ & $\mathrm{X}$ & $\mathrm{X}$ & $\mathrm{X}$ & $\mathrm{X}$ \\
\hline Ortophotomaps (geotiff) & $1: 5000$ & raster & WODGiK & $\mathrm{X}$ & $\mathrm{X}$ & $\mathrm{X}$ & $\mathrm{X}$ & $\mathrm{X}$ \\
\hline Topographical objects database & $1: 10000$ & vector & WODGiK & $\mathrm{X}$ & $\mathrm{X}$ & $\mathrm{X}$ & $\mathrm{X}$ & $\mathrm{X}$ \\
\hline Digital elevation model & $\begin{array}{l}5 \mathrm{~m} \\
\text { resolution }\end{array}$ & vector & CODGiK & & $\mathrm{X}$ & $\mathrm{X}$ & & \\
\hline Digital land cover model & $\begin{array}{l}5 \mathrm{~m} \\
\text { resolution }\end{array}$ & vector & CODGiK & $\mathrm{X}$ & & $\mathrm{X}$ & & \\
\hline Cadastral maps & $\begin{array}{l}1: 1000- \\
1: 2000\end{array}$ & vector & PODGiK & $\mathrm{X}$ & & & & $\mathrm{X}$ \\
\hline Functional areas maps & $\begin{array}{l}1: 1000- \\
1: 2000\end{array}$ & vector & ARiMR & $\mathrm{X}$ & & & $\mathrm{X}$ & \\
\hline Geosozological maps 1992 & $1: 50000$ & raster & PIG-PIB & & & $\mathrm{X}$ & & \\
\hline Sozological maps 1992 & $1: 50000$ & vector & WODGiK & & & $\mathrm{X}$ & & \\
\hline Digital forest maps & $1: 10000$ & vector & BULiGL & $\mathrm{X}$ & & & $\mathrm{X}$ & \\
\hline $\begin{array}{l}\text { Communes' natural evidence } \\
\text { and evaluation }\end{array}$ & $1: 10000$ & vector & RDOŚ & $X$ & $\mathrm{X}$ & & & \\
\hline Soil-agricultural maps & $1: 5000$ & vector & WODGiK & $\mathrm{X}$ & & & $\mathrm{X}$ & \\
\hline $\begin{array}{l}\text { Natural conservation forms } \\
\text { borders }\end{array}$ & $\begin{array}{l}1: 50000 \\
1: 10000\end{array}$ & vector & $\begin{array}{l}\text { PBPR } \\
\text { RDOŚ }\end{array}$ & & $\mathrm{X}$ & & & \\
\hline $\begin{array}{l}\text { Regional ecological patches and } \\
\text { corridors borders }\end{array}$ & $1: 50000$ & vector & PBPR & & $\mathrm{X}$ & & & \\
\hline $\begin{array}{l}\text { Studies of conditions and } \\
\text { directions of spatial deve- } \\
\text { lopment of municipality }\end{array}$ & $\begin{array}{c}1: 5000- \\
1: 10000\end{array}$ & raster & $\begin{array}{c}\text { Municipal } \\
\text { offices }\end{array}$ & & & & & $\mathrm{X}$ \\
\hline
\end{tabular}

Explanation of the names of the various institutions:

CODGiK - Head Office of Geodesy and Cartography

WODGiK - Regional (Voivodship) Office of Geodesy and Cartography

PODGiK - District Office of Geodesy and Cartography

ARiMR - Agency for Restructuring and Modernization of Agriculture

BULiGL - Bureau for Forest Management and Geodesy

PIG-PIB - Polish Geological Institute - National Research Institute

RDOŚ - Regional Directorate for Environmental Protection

PBPR - Pomeranian Office of Regional Planning. 
among others, gvSIG software and "Visibility (points)" module of Saga GIS program. Analysis and evaluation of the degradation of visual landscape values was carried out in several stages, using, among others, gvSIG software and "Visibility (points)" module of Saga GIS program. The partly inspirations of study methods result from studies of Ozimek et al. (2013) and Nita and Myga-Piątek (2014). As a starting point, also used were the identification of point, line and area anthropogenic objects which degrade landscape, and weighting them from 1 (poorly degrading) to 3 (strongly degrading). Using digital elevation model (DEM) and its cover (DTM), the range of visibility of these objects was determined. In order to take into account the declining influence of the object on the landscape, while moving away from it, an additional numeric layer, defined as "raster distance" was introduced; assuming that the interaction within and on the border of the object is 1 , and within a $5 \mathrm{~km}$ distance from it, it gets reduced to 0 . An effect of distance factor was calculated by the formula:

$$
\mathrm{y}=1 /(1+0.01 *(x-1))
$$

where $\mathrm{x}$ is the distance to the nearest degrading object.

After assigning, previously determined, particular weights to the impact ranges, they were summed up, for the purpose of a total evaluation of the intensity of the degradation of visual landscape values.

Analysis and evaluation of changes within the build-up area, which took place during a quarter of a century, i.e. 1987-2012, which involved determining the range of builtup plots within the two extreme periods, based on raster or vector topographic maps, orthophotomaps, and other databases, and then comparing their reach. The rate of change in the build-up areas was determined on the basis of the difference between the percentage share of development in the basic fields in 2012 and 1987. 3024 of square basic fields with a side of $250 \mathrm{~m}$ were used for the purpose of analysis and evaluation.

While analyzing the current building development and planned investment, determined on the basis of studies of the conditions and directions of spatial development of municipalities, against the structure of land cover, hypsometric and ground water features, as well as the position of the patches and ecological corridors, zones where varied spatial policy relating to management and protection of the landscape should be carried out were identified. 12 basic types of such zones and a similar number of subtypes were determined, for which the framework of trends in management and protection of the landscape was formulated.

\section{Study results}

Among the 18 types of land cover identified, the study area is dominated by forests, which occupy a total of $40.1 \%$ of the area (Fig. 2). The area is dominated by dry, fresh and moist habitats, while the forest occurs on a boggy and riparian habitats covers only $2.3 \%$ of the area. Three forests clearly stand out; two in the western part, around Kartuzy and between Borowo and Przywidz, and one in the east Otomińskie woodland. A similar area $(39.3 \%)$ is covered by agricultural area, dominated by arable land (22.8\%), and smaller area occupied by grassland (15\%). Their main complexes are located in the western part of the area - between Somonino and Borowo as well as in the central part, in Żukowo municipality. More than 5\% of the area is covered by turfland, part of which is semi-natural grasslands. However, the majority consists of abandoned farmland, mainly in Gdańsk and its surroundings, which in the future will be mainly built up. Among the significant land cover, we should also indicate water reservoirs (3\% of the area), and especially built-up areas, occupying a total of $8.5 \%$ of the area of research. It is worth notifying that the biggest part is covered by the suburban built-up area (3.8\%), a dominant bypass road between the Tri-City and Żukowo, but even more frequently between Żukowo and Kartuzy. Invested areas are complemented by the industrial $(1.3 \%)$ and communication areas $(1.1 \%)$, with a rise in frequency closer to the Tri-City. Highly degraded areas (mainly area of opencast exploitation of gravel and sands and landfill) occupy $0.5 \%$.

Referring to the urban sprawl, serving mainly for residential, commercial and industrial functions, it was found that in 1987 they used to occupy $4.15 \%$ of the study area (Fig. 5). These days, they occupied the largest areas in Kartuzy, Kiełpino and Żukowo, which is in the western and central part of the study area. In 2012, the share of such areas was $9.8 \%$, hence an increase in a quartercentury amounting to $137 \%$ (from 781 to 1,850 hectares). The center of gravity of the frequency of built-up areas moved towards the eastern part of the area, located within the districts of Gdańsk: Jasień, Kiełpino, Kowale and villages Otomin, Kowale, Lublewo in the Kolbudy municipality. In a relatively limited scope, the buildings developed within the cities of Kartuzy and Żukowo and more dynamic development took place in Kiełpino, Leszno, and Dzierżążno villages in Kartuzy municipality (western part) as well as Borkowo, Lniska, Przyjaźń, Niestępowo and Sulmin villages in Żukowo municipality (central part). Losses in the built-up areas within the study period had little significance for the balance of their surface. Referring the changes in surface development to the basic fields (Fig. 6), the highest growth rate was observed in the eastern part, in Gdańsk, Otomin and Kowale. Significant are- 

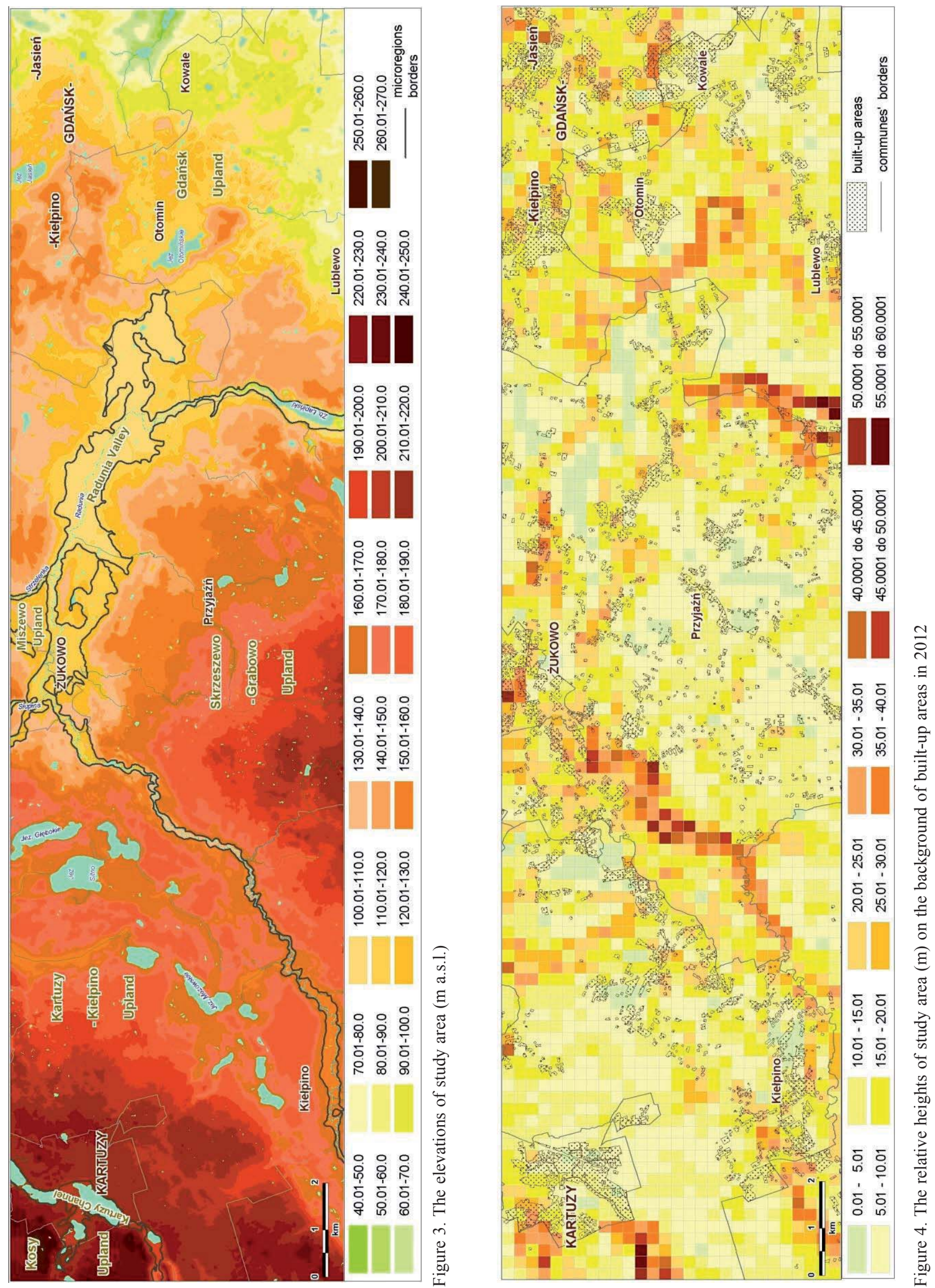

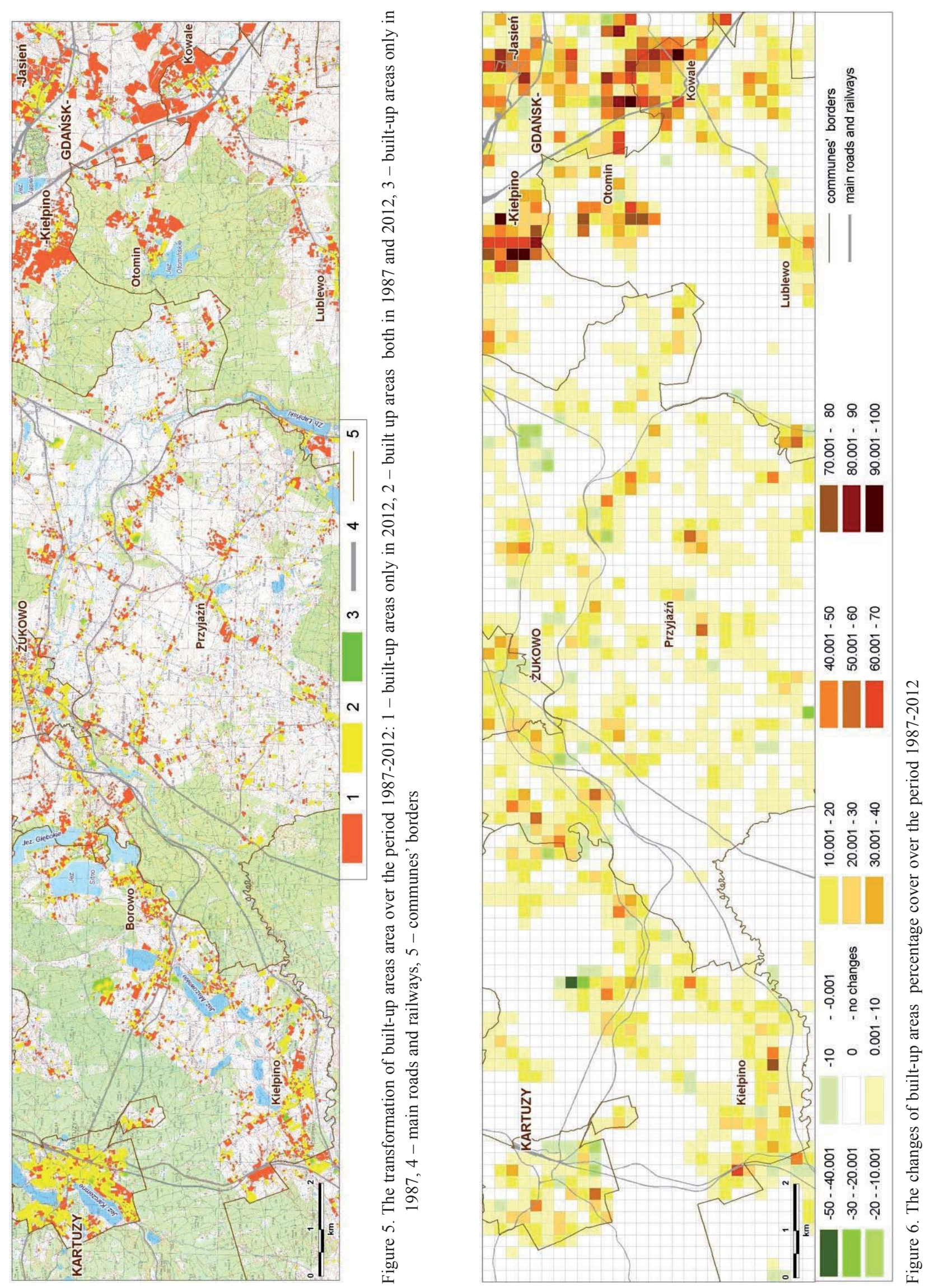
as, which were completely devoid of buildings in 1987 , are currently occupied by plots of lands with buildings at $70-100 \%$.

Comparing the range of the built-up areas to the character of the relief, referring to the basic fields $250 \times 250 \mathrm{~m}$ relative heights in particular (Fig. 4), we can observe a tendency towards building up the areas characterized by smaller relative heights - not exceeding $20 \mathrm{~m}$. This should be assessed positively from the point of view of the compatibility of the building with physiographic circumstances. The correlation coefficient of the share of built-up areas with relative height is -0.036 , which however indicates the insignificant relationship. Only in a few cases did buildings enter areas with high relief differentiation. This is particularly evident in Kowale, Lniska and Lapino, where, in the last decade, there have been built mainly single-family houses of a suburban character.

Analysis and evaluation of the degradation of visual landscape values, due to the existence and visibility of the selected anthropogenic objects (e.g. highways and road junctions, landfills, pits and dumps, industrial and energy buildings, electrical power lines, chimneys and telecommunication masts, breeding farms, suburban and summer estates, acoustic screens), indicated the highest intensity of this degradation in the central part of the area (Żukowo municipality), within Leźno, Lniska, Niestępowo, Otomino, Glińcz, Borkowo villages and in the city of Żukowo (Fig. 7).

It is the results of considerable visibility of degrading objects, as well as the high frequency of anthropogenic objects, particularly in the area of Leźno, where a central point for power is located - one of the four largest electrical substations in the region, and numerous overhead high- and medium-voltage power-lines. A significant level of degradation of visual values is observed also in Gdańsk-Szadółki (landfill of municipal wastes) and partly Gdańsk-Kiełpino as well as Lublewo (Kolbudy), Kiełpino, Dzierżążno and Borowo villages (Kartuzy municipality). The landscape of Kartuzy was assessed as poorly visually degraded. The linear correlation coefficient between the value of the index of degradation of the landscape, with an averaged basic field side of $250 \mathrm{~m}$ and a share of buildings in these fields amounting to 0.17 - however low - indicates a weak positive correlation between the increase in built-up area and visual degradation of the landscape. In this respect, the standard of living in the villages of the Żukowo municipality (Niestępowo, Lniska, Otomino) as well as in Lublewo, Kowale, Kiełpino (Kartuzy municipality) and partly in Gdańsk-Kiełpino should be assessed as the lowest with regards to visual landscape (Fig. 8).

The intensity of the process of suburbanization in the analyzed transect - rated as very high in the eastern part and significant in the central - in light of the findings of documents on spatial planning (studies of conditions and directions of spatial development of municipality), may be subject to a further increase (Fig. 9).

The current dynamics of the process and findings of studies indicate that the current, approximately 10 percent share of invested areas, may, within a few (10-20) years, be doubled, and the current population of about 100 thousand may rise to nearly 200 thousand. Moreover, there are major road projects planned for this area: the extension of the southern bypass of Gdańsk towards the west and its connection to the node Przyjaźn with a future metropolitan bypass, their links with the current road system and Kartuzy bypass, the construction of which began in 2016. The confrontation of existing and planned built-up areas and communication network with the course of the elements of ecological network, covering around $1 / 5$ of the study area (ecological patches $-5.5 \%$, ecological corridors $-15.3 \%$ ), indicate a relatively low conflict between anthropogenic and natural spatial systems. Existing buildings, outside Żukowo, by-pass the ecological corridors. However, there is a risk, that the planned investment will interfere with some ecological corridors, reducing the efficiency of their operation. This may occur mainly in the area of Żukowo, Niestępowo, Łapino, Borowo and Mezowo in the central part of the study (Fig. 9). Specific environmental problems may occur during construction and operation of the metropolitan ring road in the three zones, which intersect the ecological corridor of Radunia valley, in the vicinity of Żukowo, Lniska and Widlino.

\section{Discussion of the results and proposed lines in landscape management and protection}

Identification, analysis and assessment of natural and anthropogenic elements of the study area allowed the delimitation of zones in which varied policies in landscape management and protection should be carried out. 12 basic types of such zones and the same number of subtypes were identified, which occurred in 145 diverse spatial policy areas (Fig. 10). The characteristics of these types are presented in Table 2.

In zone A, it is desirable for sustainable forest management, particularly, within the patches and ecological corridors. Due to the functional variety of large forests, which include, among others, important recreational areas, it is advisable to implement the principles of multifunctional forest management, given, among others, by Miś (2007). Acquiring stands, which grow in the boggy and riparian habitats should be minimized. Both in A and B zones, the agricultural and habitat- forestry border should be shaped in such a way that it minimizes the negative impacts of the environment on the forest. The area of small forest complexes should not be reduced, and, if possible, should rather 

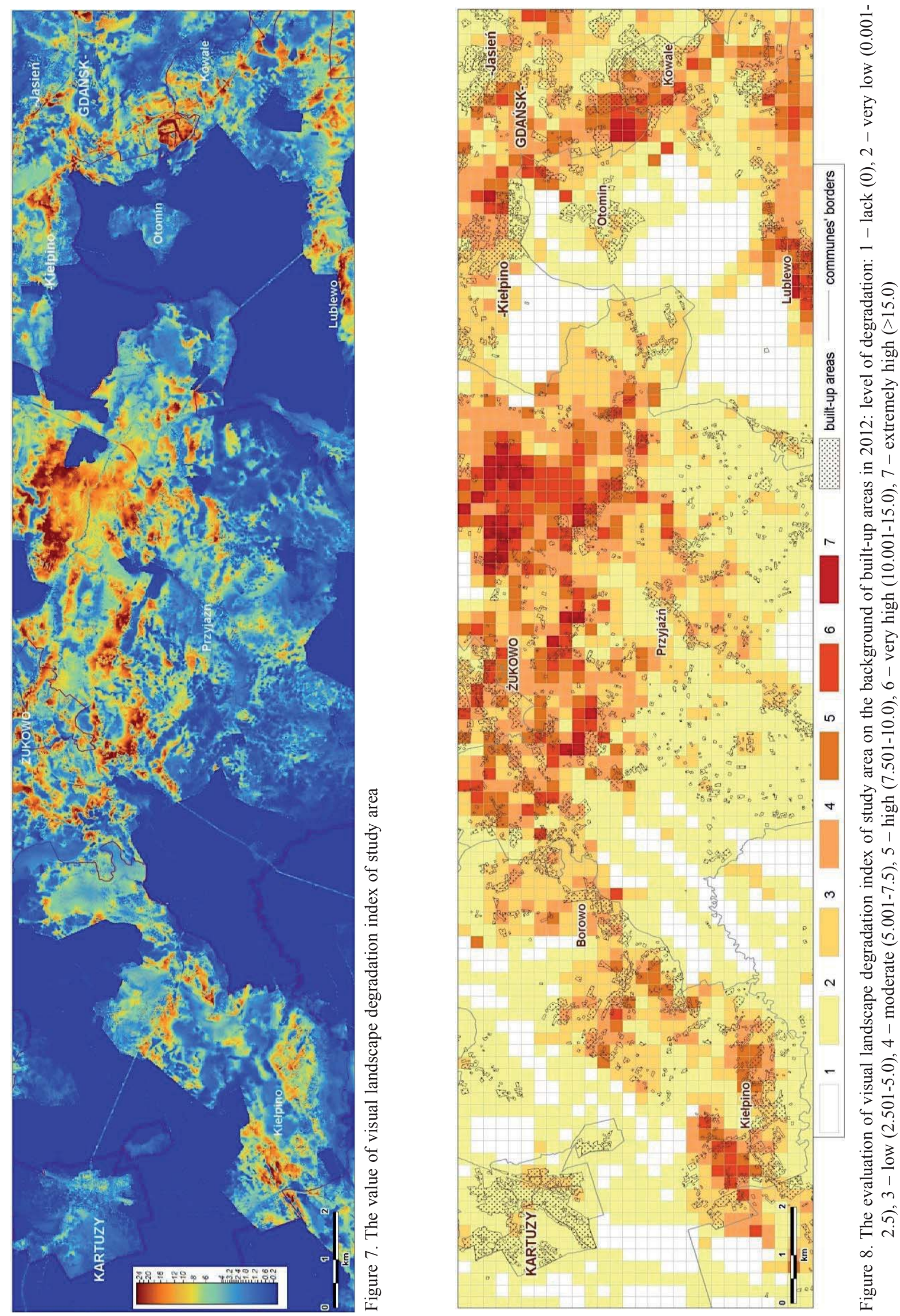
be increased. In zone C, including Karczemne and Jasień Lakes along with the environment, the expansion of development within a 100-meter zone around the lake should be minimized. It is very important to maintain or restore a high quality of reservoirs' waters, primarily by eliminating sources of pollution which enter them. The surrounding greenery should be nurtured, and where absent should be introduced. It must be so shaped to maintain significant exposure reservoirs, and at the same time allow the public to use recreational coastal zones, through the development of waterfronts.

The basic principle of management in zone $\mathrm{D}$, should be focused on: maintaining its spatial continuity, by, among others, minimizing the introduction of new investment, including the technological dominants (e.g. telecommunication masts, overhead power-lines); maintenance of the avenues and tree rows as well as their view connections with local interior landscape; preservation and revitalization of settlement traces of Kashubian single-homestead dispersed settlements; avoiding dispersion of new buildings and using, in case of its location, any architectural forms; maintaining the spatial structure surrounded by water bodies; protection and establishment of green fields; maintenance and sometimes reconstruction of all natural and semi-natural water objects (ponds, swamps). It is important to maintain a significant share of grassland (meadows and pastures) in the structure of agricultural land (about $1 / 3$ of the area).

In Zone $\mathrm{E}$, it is recommended to maintain the existing structure of agricultural land, including historical land divisions, as significant exposure zones of settlement units located in their neighborhood. New buildings should be avoided especially in areas with high level of morphodynamic processes and terrains where shallow groundwater occurs. Allotment gardens in the E3 subtype should be maintained only in those areas where the quality of the environment (mainly air) does not exceed the standards which enable the production of healthy food. In other cas-

Table 2. Characteristics of the types of zones with varied policies of landscape management and protection

\begin{tabular}{|c|c|c|c|c|}
\hline \multirow{2}{*}{$\begin{array}{l}\text { Code of } \\
\text { zones' } \\
\text { type }\end{array}$} & \multirow{2}{*}{ General characteristics of zones } & \multicolumn{2}{|c|}{ Total area } & \multirow{2}{*}{$\begin{array}{l}\text { Number of } \\
\text { individual zones }\end{array}$} \\
\hline & & ha & $\%$ & \\
\hline A & $\begin{array}{l}\text { Big woodland complexes with subtypes with bigger valleys } \\
\text { (A1) and lakes (A2) }\end{array}$ & 7053.0 & 37.3 & 8 \\
\hline $\mathrm{B}$ & $\begin{array}{l}\text { Small woodland complexes with subtypes in valleys (B1) and } \\
\text { with lakes (B2) }\end{array}$ & 446.4 & 2.4 & 15 \\
\hline $\mathrm{C}$ & $\begin{array}{l}\text { Bigger lakes with mainly wooded shores and subtype with non- } \\
\text { wooded surrounding }(\mathrm{C} 1)\end{array}$ & 111.5 & 0.6 & 2 \\
\hline $\mathrm{D}$ & $\begin{array}{l}\text { Mosaic of farmland with a great share of grassland and small } \\
\text { woodland complexes with subtype located in valley } \\
\text { and the low lands (D1) }\end{array}$ & 1988.0 & 10.6 & 14 \\
\hline $\mathrm{E}$ & $\begin{array}{l}\text { Agricultural area, mainly cropland with subtypes: with } \\
\text { dispersed homestead (E1), with the areas designed as a built-in } \\
\text { (E2) and dominance of allotment gardens (E3) }\end{array}$ & 4709.0 & 25.0 & 25 \\
\hline $\mathrm{F}$ & $\begin{array}{l}\text { Dense rural settlement (and farms, services and recreational } \\
\text { areas connected with it) with a subtype covering the areas } \\
\text { designed as a built-in and agricultural areas (F1) }\end{array}$ & 1800.0 & 9.6 & 35 \\
\hline G & $\begin{array}{l}\text { Suburban settlements with the areas designed as built-in and } \\
\text { agricultural areas, with a subtype covering former agricultural } \\
\text { areas designed as a built-in (G1) }\end{array}$ & 1562.0 & 8.3 & 25 \\
\hline $\mathrm{H}$ & Dense settlement of a small-town character & 315.3 & 1.7 & 3 \\
\hline I & Dense big-city settlement, mainly multi-family housing & 487.5 & 2.6 & 8 \\
\hline $\mathrm{J}$ & Magisterial communication lines, mainly roads & 105.7 & 0.6 & 2 \\
\hline $\mathrm{K}$ & $\begin{array}{l}\text { Industrial and warehousing areas, with a subtype covering the } \\
\text { agricultural areas and areas designed as a built-in (K1) }\end{array}$ & 203.8 & 1.1 & 4 \\
\hline $\mathrm{L}$ & Areas of open pit mining of sand, gravel and clay & 44.23 & 0.2 & 4 \\
\hline
\end{tabular}



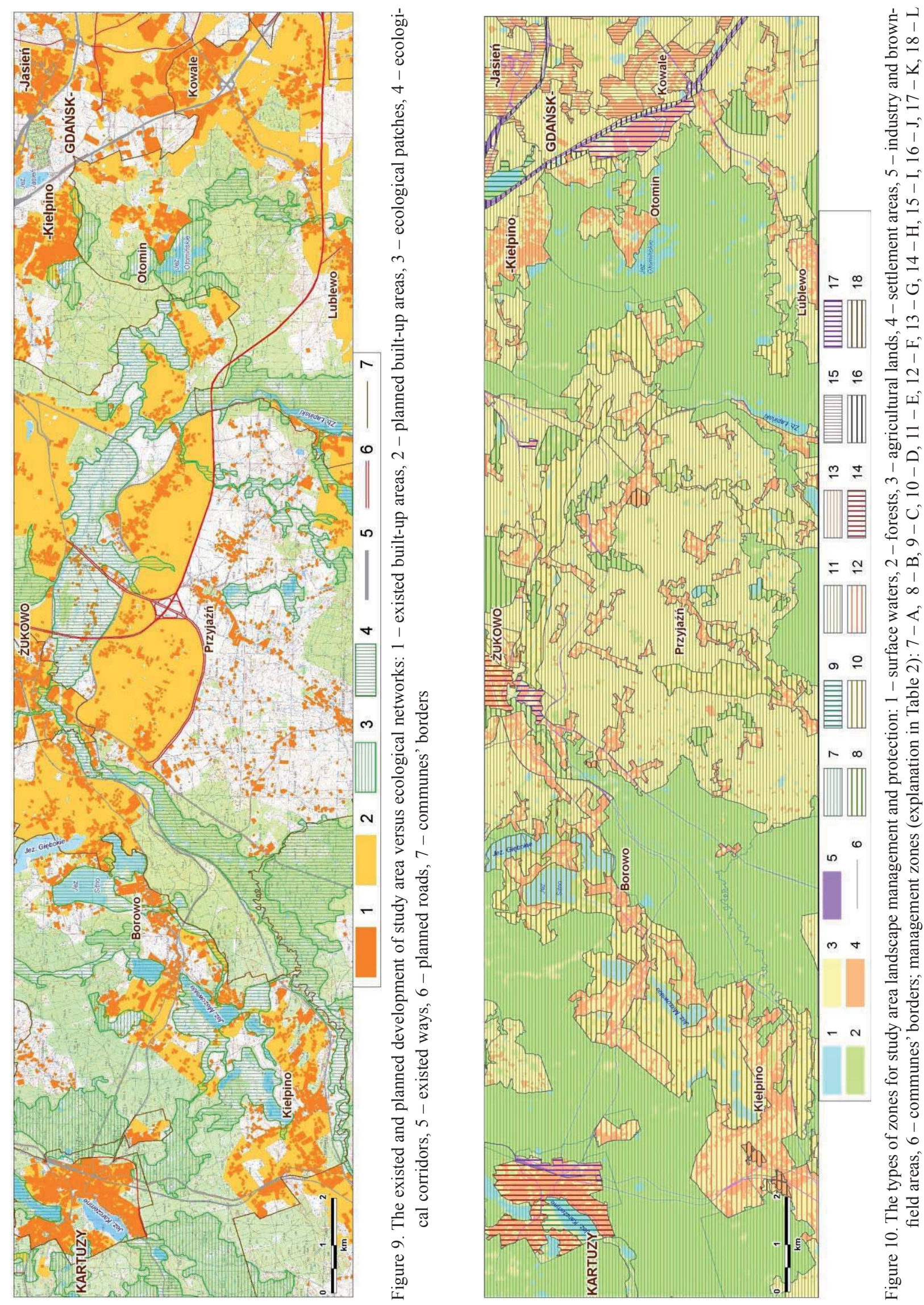
es, their transformation into public greenery of recreational functions should be made.

In Zone $\mathrm{F}$, it is advisable to use planning practices leading to maintenance of spatial order and harmonization of investments along with natural elements, executed by protecting or improving the exposure of a panoramic contour of historical rural units, preservation and continuation of the specifics of the historical layout of settlements, avoiding the use of any forms of architecture in the new building developments, the preservation and continuation of historical and regional building scale, introducing composed greenery and semi-natural elements (water, vegetation) within existing and new settlement units. In some areas it is necessary to eliminate the causes of degradation of spatial structure (e.g. the sheer volume of outdoor advertising banners, arbitrary architectural forms and styles, diversity of elevation, etc.) as well as architectural revitalization, along with saturation by natural elements (greenery), especially in areas of environmental functions (local ecological corridors). Vast areas planned for investment should be covered by the principles of sustainable, and in some places even environmentally friendly, architectural development (Baranowski, 1998).

In Zone $\mathrm{G}$ (suburban development), due to the deficit of public spaces and generally accessible recreation and leisure greenery, further building development within ecological corridors should be avoided, and eliminate common drawbacks of this type of settlement (especially monofunctionality) in other areas. The functions of ecological corridors situated in their vicinity should be combined with the functions of leisure and recreational facilities. In Zone $\mathrm{H}$, which is within the urban areas of Kartuzy and Żukowo, management should be developed in a manner which maintain the permeability of ecological corridors, among others by introducing and maintaining buffer greenery. The exposure of units of historic buildings and entire panoramic contour of historical urban or rural areas hereby located in the landscape should be protected and improved. Moreover, the exposure of objects to negative impacts, such as the industrial and substandard, should be limited while other causes of deterioration of spatial structure (similarly to the Zone F) should be eliminated. Zone I, which, within the study area, covers primarily multifamily housing estates of Gdańsk built in the twenty-first century, requires first and foremost the development of other functions (mainly services) - except for housing - as well as the formation of local ecological network in the form of housing estate greenery. During the investment process, it is recommended to maintain the majority of elements of greenery and water bodies existing in the area before construction and to use them in shaping the housing estate area.

In Zone J, routes and their proximity should be designed, implemented and used in accordance with ecological principles of landscaping work for roads, indicated in the development of Forman et al. (2003). Industrial and storage areas located in Zone $\mathrm{K}$, are located primarily on the outskirts of Gdańsk, Kartuzy and Żukowo. Due to the nature of the activities being carried out in this area, the possibilities for a sustainable development of their space are limited. What seems to be most essential is to limit the negative impacts of their operations, by isolating them from the surrounding areas, especially settlement and recreational ones, which is, among others, a result of the location of the buffer greenery. The areas of opencast mining of sand and gravel, which are located in zone L, must be exploited in such a manner that would minimize changes in the natural environment and landscape, e.g. according to the principles set by Olschowy (1975).

\section{Conclusions}

Trends in shaping the landscape of the study area based on natural criteria were already the subject of interest to researchers in the 80s of the 20th century (Przewoźniak, 1985). Directives formulated at that time are still valid today, however, some of them were not taken into account during the process of planning and implementation of investments for this area in the last 30-year period. Due to the crucial importance of the analyzed area for the maintenance of spatial structural order as well as high quality of life for the inhabitants of Gdańsk agglomeration and its surroundings, during preparations of spatial plans at the sub-regional and local level, one should strive to, the broadest possible, take into account the principles and recommendations presented in the article, as well as implementation of its findings.

\section{References}

Ahmad F., Goparaju L., 2016, Analysis of Urban Sprawl Dynamics Using Geospatial Technology in Ranchi City, Jharkhand, India, Journal of Environmental Geography 9(1-2): 7-13.

Antrop M., 2004, Landscape change and the urbanization process in Europe. Landscape and Urban Planning, 67(1-4): 9-26.

Baranowski A., 1998, Projektowanie zrównoważone $\mathrm{w}$ architekturze [Sustainable design in architecture]. Wydawnictwo Politechniki Gdańskiej, Gdańsk.

Forman R.T.T., 1995, Land mosaics: the ecology of landscapes and regions. Cambridge University Press, Cambridge.

Forman R.T.T., Sperling D., Bissonette J., Clevenger A.P., Cutshall C., Dale V., Fahrig L., France L., Goldman C., Heanue K., Jones J., Swanson F., Turrentine T. \& Win- 
ter T., 2003, Road Ecology: Science and Solutions. Island Press, Covelo, CA.

Kamieniecki K. (ed.), 2002, Miasto za miastem [City behind the city], Raport 3. Instytut na Rzecz Ekorozwoju, Warszawa.

Kistowski M., 2015, Rozpoznanie i ocena stanu walorów krajobrazowych trzech obszarów chronionego krajobrazu położonych w województwie pomorskim (Otomińskiego, Doliny Raduni i Kartuskiego) pod kątem zgodności z kryteriami wyznaczania obszarów chronionego krajobrazu, określonymi w art. 23 ust. 1 ustawy o ochronie przyrody - wraz z oceną zasadności zasięgu przestrzennego tych obszarów [Diagnosis and evaluation of landscape values state of three landscape protection areas in Pomeranian Province according criteria of landscape protection areas delimitation definite in art. 23.1 of Nature Conservation Act - with evaluation of validity of spatial dimension of these areas]. Zarząd Województwa Pomorskiego, Gdańsk.

Kistowski M. \& Korwel-Lejkowska B., 2009, Zmiany w systemie przyrodniczym Metropolii Trójmiejskiej stan i wskazania dla przyszłego rozwoju [Dynamics of natural system of Tri-city metropolis - condition and hints for future development]. Studia KPZK PAN CXXIII: $124-140$.

Kistowski M. \& Szydłowski J., 2015, Zastosowanie GIS w delimitacji regionów fizycznogeograficznych w kontekście wdrażania Europejskiej Konwencji Krajobrazowej [GIS application for physico-geographical regions delimitation in the context of European Landscape Convention delimitation]. Problemy Ekologii Krajobrazu XL: 161-176.

Manakos I. \& Braun M. (eds), 2014, Land Use and Land Cover Mapping in Europe. Practices \& Trends. Springer, Netherlands.

Miś R., 2007, Urządzanie lasów wielofunkcyjnych [Multifunctional forests management]. Wydawnictwo. Akademii Rolniczej im. Augusta Cieszkowskiego w Poznaniu, Poznań.

Nita J. \& Myga-Piątek U., 2014, Scenic Values of the Częstochowa-Katowice Sectio of National Road No 1. Geographia Polonica 87(1): 113-126.
Olschowy G., 1975, Zakłady przemysłowe [Industry factories], [in:] K. Buchwald \& W. Engelhardt (eds), Kształtowanie krajobrazu a ochrona przyrody, [Landscape management and nature conservation]. Państwowe Wydawnictwa Rolnicze i Leśne, Warszawa.

Ozimek P, Böhm A., Ozimek A. \& Wańkowicz W., 2013, Planowanie przestrzeni o wysokich walorach krajobrazowych przy użyciu cyfrowych analiz terenu wraz z oceną ekonomiczną [High landscape values spaces design with application of digital terrain analysis with economical evaluation]. Wydawnictwo Politechniki Krakowskiej, Kraków.

Przewoźniak M., 1985, Przyrodnicze uwarunkowania przestrzennego rozwoju Aglomeracji Gdańskiej [Natural conditions of Gdańsk agglomeration spatial development]. Zeszyty Naukowe Wydz. BiNoZ Uniwersytetu Gdańskiego, 13: 79-91.

Richling A., \& Solon J., 2011, Ekologia krajobrazu [Landscape ecology]. Wydawnictwo Naukowe PWN, Warszawa.

Sołtys J., 2006, Żywiołowe procesy urbanizacji w strefie podmiejskiej aglomeracji gdańskiej [Spontaneous urbanization processes in suburban zone of Gdańsk agglomeration], [in:] S. Kozłowski (ed.), Żywiołowe rozprzestrzenianie się miast. Narastający problem aglomeracji miejskich w Polsce [Spontaneous urban sprawl. Escalating problem of Polish urban agglomerations]. Studia nad zrównoważonym rozwojem, II, Wydawnictwo Ekonomia i Środowisko, BiałystokWarszawa: 225-241.

Studium korytarzy ekologicznych w województwie pomorskim - dla potrzeb planowania przestrzennego [Study on Ecological corridors of Pomeranian province - for spatial planning], 2014, Pomorskie Biuro Planowania Regionalnego, Słupsk.

Urban sprawl in Europe, 2006, EEA Report, 10/2006. European Environmental Agency, Copenhagen.

Ustawa z dnia 16 kwietnia 2004 r. o ochronie przyrody, Dz.U. 2018 poz. 142, 2018, Kancelaria Prezesa Rady Ministrów [Nature Conservation Act of 16 April 2004, Journal of Laws 2018 item 142, 2018, Chancellery of the Prime Minister], Warszawa. 